\title{
A Stain on Humanity: Child Mothers Below the Age of 10 Years
}

\author{
Erdal Özer ${ }^{1},{ }^{2}$, İsmail Birincioğlu ${ }^{3}$, Halil İlhan Aydoğdu ${ }^{2}$, Seckin Güven Kurc1 ${ }^{2}$, Hasan Okumuş ${ }^{2}$, Mehmet \\ Askay $^{2}$, Zehra Aydoğdu Aslan ${ }^{4}$, Filiz Özer ${ }^{5}$ \\ ${ }^{1}$ Karadeniz Tecnical University, Institute of Forencis Sciences, Trabzon/Turkey \\ ${ }^{2}$ Karadeniz Tecnical University, Faculty of Medicine, Internal Medicine, Department of Forensic Medicine, Trabzon/Turkey \\ ${ }^{3}$ Balikesir University, Faculty of Medicine, Internal Medicine, Department of Forensic Medicine, Balikesir / Turkey \\ ${ }^{4}$ Karadeniz Tecnical University, Faculty of Medicine, Internal Medicine, Department of Family Medicine, Trabzon/Turkey \\ ${ }^{5}$ Ordu University, Institute of Social Sciences, Ordu/Turkey
}

Received: 27 November 2016, Accepted: 2 August 2017, Published online: 28 August 2017

(C) Ordu University Institute of Health Sciences, Turkey, 2017

\begin{abstract}
Objective: The concept of child mothers includes individuals who have given birth below the age of 18 years. In this study, the subject is addressed of individuals who have given birth at a much younger age (10 years and below).

Material and methods: Studies were examined from different countries to examine the information on the ages of cases, types of birth and by whom they had been made pregnant.

Results: The child mothers had been made pregnant by the husband in $3(3 \%)$ cases, by the step-father in 11 $(12 \%)$ cases, by a relative in $30(32.4 \%)$ cases and by others in $35(37.8 \%)$ cases. In 29 caes $(31.3 \%)$ the identity of the father was not known.

Conclusion: This study aimed to be a reminder of the need to overcome child abuse, which is masked by the excuses of religion or tradition, by presenting a reminder of the reality of 'mothers below the age of 10 years'. Better identification and increased awareness of child abuse will prevent the confusion of it with the historical concept of child mother. By presenting a reminder of one of the greatest shames of humanity in the last century, it is aimed to create an awareness against the concept of child abuse and child bride/child mother.

Key words: Child mothers, child abuse, pregnancies at a young,
\end{abstract}

Address for correspondence/reprints:

Halil İlhan Aydoğdu

Telephone number: +904623775913

E-mail: ilhanaydogdu@gmail.com

DOI: $10.19127 / \mathrm{mbsjohs} .267178$

Note: This article was presented as a poster at the 12th Congress of Forensic Sciences

\section{Introduction}

The process of modernization which accelerated together with the Industrial Revolution equipped humanity with all the possibilities of technology but unfortunately did not reveal more moral individuals. Child abuse which is encountered in several cases from mythology continues in the most brutal form (Ozer et al, 2014). Humanity came to the point where the unnaceptable concept of child mothers became a concept. Nevertheless, as will be discussed in this paper, traditions and customs and religious beliefs have normalised this and legal deficiencies have legitimised this situation in places. According to the Convention on the Rights of the Child, Article 1, 'For the purposes of the present Convention, a child means every human being below the age of eighteen years unless under 
the law applicable to the child, majority is attained earlier' (Çocuk Haklarına Dair Sözleşme, 1995). Therefore, the concept of child mothers is valid for all mothers under the age of 18 years. In this study, the subject is addressed of cases in global medical literature and global media of mothers aged 10 years and below (List of youngest birth mothers). From a medical and legal perspective, the statistical data are presented of 108 child mothers including the geographical distribution, by whom they were made pregnant and the methods of giving birth.

In the period from birth to puberty, together with hormonal maturation, secondary sex characteristics start to develop (Sadler, 2000). The onset of menarche, generally at 11-12 years is accepted as a sign of entering the child-bearing period. However, entering the child-bearing period does not mean that the genital system has matured. The system continues to mature until approximately the age of 21 years (Guyton and Hall, 2005).

According to the general international acceptance that an individual below the age of 18 years is a 'child', the marriage of such individuals is known as 'child marriage'. In the modern Turkish legal system, articles which refer to the concept of child and child marriage are: Turkish Civil Law, Article 124, 'Males and females below the age of 17 years cannot marry. However, in extraordinary circumstances and for an important reason, the judge may give permission for a man or a woman aged 16 years to marry. When possible, the decision primarily rests with the mother and father or guardian' (Guyton and Hall, 2005). In Turkish Criminal Law, Article 104: 'Any person having sexual relations with a child over the age of 15 years, without resorting to force, threats or deceit, shall upon complaint be punishable by imprisonment of two to five years'. In Turkish Civil Law, Article 12 it is stated that 'a child below the age of 15 years can be rendered legally an adult by the court on their own request and with the consent of their parents (Turkish Civil Code). As can be understood from the relevant legal articles, the door has been left open by the legal system for child marriages at the age of 15 years.

In very exact Word, marriage in early ages or child maternity is to take by hands woman's life. (Aydemir, 2011). Violence against woman and woman abuse imprisoned in gender role are getting permanet and it definitely destrosy woman identity.
In this study, by presenting a reminder of one of the greatest shames of humanity in the last century, it was aimed to create an awareness against the concepts of child bride and child mother, which from time to time, religion, customs and tradition have tried to make an accepted practice by society.

\section{Methods}

The research included cases of child mothers (510 years) in medical literature or which have featured as news in local and international media. During the research "child mother" "child bride" and 5 to 10 ages pregnant terms are used, respectively. If the information was available in the news or articles, statistical evaluation was made in respect of the identity of the father, the country or continent where the mother lived, the method of birth and whether or not the infant survived. The results obtained were evaluated for frequency distribution using Microsoft Office 365 Excel program. The term 'relative' used in this study encompasses father, brother, uncle by blood or marriage, cousin and grandfather.

\section{Results}

The age of the 108 child mothers ranged from 510 years; $1(0.92 \%)$ was 5 years old (Vaughan, 1933), 2 (1.85\%) were 6 years old, $9(8.3 \%)$ were 8 years old, $27(25 \%)$ were 9 years old and $69(63.8 \%)$ were 10 years old (Josiah, 1863) [Graphic 1]. The mean age was determined as 9.46 years. The place of residence was on the American continent in 76 (82\%) cases, in Africa in $13(14 \%)$ cases, in Asia in $12(12.9 \%)$ cases and in Europe in $9(9.7 \%)$ cases. On a country basis, 28 (25.9\%) were reported from the USA, so the USA was determined as the country where most cases were seen. The child mothers had been made pregnant by the husband in $3(3 \%)$ cases, by the step-father in $11(12 \%)$ cases, by a relative in $30(32.4 \%)$ cases and by others in $35(37.8 \%)$ cases. In 29 cases $(31.3 \%)$ the identity of the father was not known [Graphic 2]. Birth was by the vaginal route in 47 cases and by caesarean operation in 45 . The manner of birth was not known in 16 cases. Of the infants delivered to the 108 child mothers, 9 died at birth. No information was available about the health of the other infants. 


\section{AGE DISTRIBUTION}

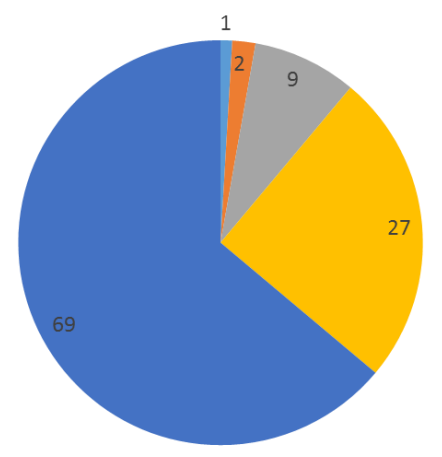

匹 5 YEARS OLD $\approx 6$ YEARS OLD $\square$ Y YEARS OLD

9 YEARS OLD $=10$ YEARS OLD

Graphic 1: Age distibution

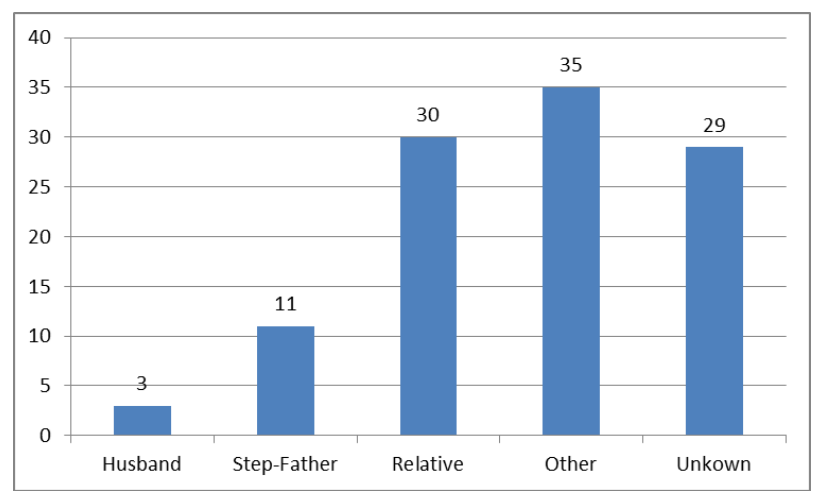

Graphic 2: Fathers

\section{Discussion}

The concept of child mothers is not foreign to humanity. From the reviews of articles and news, 1 case of a child mother aged 10 years or below was determined in Turkey. On a country basis, the most cases were seen in the USA with 28 cases and on the basis of continents, $76(82 \%)$ were in America, followed by 13 (14\%) in Africa, 12 (12.9\%) in Asia and $9(9.7 \%)$ in Europe. The child mothers were made pregnant by the husband in $3(3.2 \%)$ cases and as the result of rape by a relative in $30(32.4 \%)$ cases and by the step-father in $11(12 \%)$ cases, the father in the remaining 64 cases was outside the family or could not be determined. If step-fathers are considered as family members, then 41 (44.2\%) cases were the result of an incestuous relationship.
However, as the vast majority of the data obtained was from news reports, it can be considered that this statistical study could not provide meaningful results, which could be related to the accumulated knowledge and extent of the research. When the methods of birth of the child mothers were examined, discounting the 16 cases where the method of delivery was unknown, $47(51 \%)$ cases were vaginal delivery and $45(49 \%)$ were by caesarean operation. In retrospective studies conducted in Turkey, rates of caesarean delivery have been reported as 18\%-33\% (Guney et al, 2006, Yilmaz et al, 2008, Yildiz et al 2010, Caglayan, 2011). The high rate of caesarean section operations in the child mothers of $49 \%$ can be associated with the female genital system not having reached maturity. As stated in previous studies, that the process of development and maturation of the female genital system has not been completed can be the primary reason for physical and psychosocial problems in sexual relations, pregnancy, birth and confinement periods (Ozer et al,2014). In addition, that the child mothers have not even entered adolescence can be the subject of further research in respect of psychiatric problems experienced. Separate studies should be planned to ascertain what happened to the infants at a later stage.

\section{Conclusion}

Unfortunately, even the concept of 'child mother' is not sufficient to encompass the cases of pregnancies at the age of 10 years or younger. Although accepted as a shame of humanity, there has been an extreme delay in defining this as "child abuse' but in the last decade there has been observed to be a change in the awareness of physicians and society to the concept of child abuse. The greatest hindrance to this positive development is grandparents and religious-based beliefs and that society has remained at an inadequate level of education. All kinds of discourse and thoughts supporting child abuse, even indirectly and even if said in the name of religion, must be fought.

In terms of the data we have the significant parts of cases were observed in America. But, this study was done through media information so it can be deceptive. It is more possible to encounter this kind of cases in countries where awareness is higher. For the sake of the nation and of all humanity, there cannot be any compromise on the subject of child abuse. For every compromise that is made, it must not be forgotten that as in the cases reported here, there will be mothers of an extremely young age. 
Informed Consent: Written informed consent was obtained from students who participated in this study.

Peer-review: Externally peer-reviewed.

Author Contributions: Concept -E.O., Design E.O., I.B; Supervision H.O., G.S.K; Materials M.A., G.S.K., H.O; Data Collection and/or Processing - F.O., E.O., M.A; Analysis and/or Interpretation - H.I.A, Z.A.A; Literature Review M.A, H.I.A; Writing - H.I.A., M.A; Critical Review- E.O., I.B.

Conflict of Interest: No conflict of interest was declared by the authors.

Financial Disclosure: The authors declared that this study has /hasn't received no financial support.

\section{References}

Aydemir, E. Evlilik mi evcilik mi? Erken ve zorla evlilikler: Cocuk gelinler. International Strategic Research Organization (USAK). 2011

B.M. Çocuk Haklarına Dair Şözleşme- Bkz: http://www.unicef.org/turkey/crc/_cr23c.html Accessed: 15/01/2016

Curtis, Josiah. "A Girl Aged Ten Years, Eight Months, and Seven Days, Delivered of a Healthy Child at the Full Time of Pregnancy". Boston Medical and Surgical Journal, 1863; 67 (3): 4951.

Caglayan E., Kara M, Cihan Gürel Y. Cesarean section rate and indications in our clinic to theree years, J Exp. Clinical Med. 2010; 27, 50-53

Guyton\&Hall: T1bbi Fizyoloji 11. Basim

Guney, E., Uzun, E., Oral, B., Sarıkan, İ., Bayhan, G., Mungan, T. Cesarean section rates and indications at our clinic between 2001 and 2005. J. Turk. Soc. Obstet. Gynecol. 2006; 3: 249-254.

List of youngest birth mothers Bkz:

http://en.wikipedia.org/wiki/List_of_youngest_b irth_mothers\#cite_note-35_ Accessed: $15 / 01 / 2016$

Ozer, E., Nacar, M. C., Yildirim, A., Enginyurt, O., Din, H., \& Evcuman, D. Underage mothers in Turkey. Medical science monitor: international medical journal of experimental and clinical research, 2014; 20, 582.

Ozer, E., Tokdemir, M. B., Yıldırım, A., Koçak, U., Bütün, C., \& Enginyurt, Ö. Mitolojide çocuk istismarı olguları. Cumhuriyet Medical Journal, 2014: 36(1), 111-115.
T.W. Sadler: Langmann Medikal Embriyoloji 2000. Turkish Civil Code. Bkz: http://www.tbmm.gov.tr/kanunlar/k4721.html Accessed: 15/01/2016

Vaughan, K. Pregnancy in childhood. British medical journal, 1933; 2(3798), 759.

Yildiz, A., Koksal, A., Cukurova, K., Keklik, A., Celik, N., İvit, H. Bir Obsetetrik Kliniğinde 15 y1llk period süresince sezaryen oranları ve endikasyonlarının yıllara göre dağılımı. Nobel Med. 2010; 6, 10-14.

Yilmaz, E., Kara, M., Okumuş, B., Aran, E., 2008. Ağrı il Merkezinde 2004 ve 2007 y1llarındaki Doğumların Karşılaştırılması. Perinatoloji Derg. 2008; 16, 26-31. 